\title{
EFFECTS OF TYPE SPORTS ON PULMONARY FUNCTION TESTS: A COMPARATIVE STUDY IN NEPALESE SETTINGS
}

\author{
Narayan Bahadur Mahotra and Lava Shrestha
}

\begin{abstract}
:
Introduction: Due to regular exercises, athletes tend to have an increase in pulmonary capacity when compared to non-exercising individuals. Intensity and severity of sports engaged in by the athletes probably determines the extent of strengthening of the inspiratory muscles with a resultant increase in the pulmonary functions. ${ }^{1,2}$ So, this study has been carried out to establish a relationship between the type of sports and pulmonary functions in Nepalese athletes.
\end{abstract}

Methods: This study has adopted a cross sectional observational comparative research design. Spirometry was conducted in 84 different national level athletes [25.71 $( \pm 4.55)$ years]. The athletes were from five different sport groups. Out of them, there were 16 weight lifters, 41 footballers, 10 swimmers, 8 marathon runners and 9 sprinters. Among them weight lifters, marathoners and sprinters were selected from the National sports council, Tripureshower, Kathmandu and footballers and swimmers were from the Nepal army club, Kathmandu, Nepal.

The spirometry was done in sitting position using MIR SPIROLAB II spirometer based on American Thoracic Society (ATS) recommendations. Pulmonary function was assessed based on Forced Expiratory Volume in first second $\left(\mathrm{FEV}_{1}\right)$, Forced Vital Capacity (FVC) and Peak Expiratory Flow Rate (PEFR) expressed as percent predicted for the age, sex, height, weight and race.

Results: When comparing the mean values of FVC, FEV 1 and PEFR among the five different sport groups, as expected, athletes who have more strenuous respiratory muscles exercise had significantly superior pulmonary function parameters. For example weight lifters and swimmers had 111.84 and 109.56 percentage of predicted values on $\mathrm{FVC}(\mathrm{P}=0.008)$ respectively. But marathoners, footballers and sprinters had 105.83, 99.25 and 98.34 percentage of predicted values respectively. Similarly, weight lifters, swimmers, marathoners, footballers and sprinters had 110.63, 110.15 and 110.28, 102.52 and 99.23 percentages of predicted values on $\mathrm{FEV}_{1}(\mathrm{p}=0.090)$ respectively. Swimmers, marathoners, footballers, weight lifters and sprinters had 106.03 and 107.34, 104.37, 102.08 and 86.58 percentage of predicted values on PEFR $(\mathrm{p}=0.027)$ respectively.

Conclusion: Athletes who have most strenuous respiratory muscle exercise like swimming and weight lifting have better pulmonary function tests (PFTs) compared to other athletes like sprinters who have less strenuous muscle exercise.

Key words: athletes, FEV,$F V C$, and PEFR, pulmonary function test

\section{Introduction:}

Pulmonary function is governed by genetic, environmental and nutritional factors and confirms that physical training during growth help in developing a greater endurance in respiratory muscles. Lung size may increase by a strenuous and prolonged strength training 


\section{Original Article}

regimen during adolescence. ${ }^{3}$ significant difference in pulmonary functions is found among types of athletic training. Swimmers have better pulmonary functions because in swimming the load of water pressure against the chest wall and elevated airway resistance as the result of immersion causes increase in the exercise of respiratory muscles. ${ }^{4}, 5$ American athletes have superior lung volumes compared to Indian athletes, because of athletic training from the childhood in American athletes. ${ }^{6}$ Vital capacity of Indians is lower than that of Caucasians, but the age related decline is much greater for caucacians. ${ }^{7}$

Besides sedentary lifestyles, respiratory performance is affected by various factors like air pollution. ${ }^{7}$ Ethnic variations as well as the variation in age, body size and level of physical fitness influence the pulmonary function tests. ${ }^{8}$ Pulmonary function shows variation owing to differences in growth and because of the possibility that those subjects would not have reached their adult weight for body mass index (BMI). ${ }^{8}$ Pulmonary function values in health are also influenced by some unknown variables and there are wide ranges of normalcy. ${ }^{9,10,11}$

Training improves physical working capacity. A trained sportsman has a resting bradycardia and a greater maximum $\mathrm{O}_{2}$ consumption ability $\left(\mathrm{VO}_{2}\right.$ max $)$ but small percentages of athletes develop exercise induced bronchospasm and thereby reduced PFTs. ${ }^{9,11}$,

\section{Methods:}

This is the cross sectional observational comparative study. Spirometry was conducted in 84 [mean age $25.71( \pm 4.55)$ years] national level athletes from different sports. The athletes were from five different sport groups. Out of them, 16 were weight lifters, 41 were footballers, 10 were swimmers, 8 were marathon runners and 9 were sprinters. Among them weight lifters, marathoners and sprinters were selected from the National Sports Council,
Effects of Sports on pulmonary functions

Tripureshower, Kathmandu and footballers and swimmers were from the Nepal Army Club, Kathmandu, Nepal. Data was collected based on ATS questionnaires. The athletes were selected based on the mutually exclusive and nonoverlapping sampling technique. Those athletes failing to perform the test successfully and those having respiratory or cardiovascular diseases according to the ATS questionnaires and smokers were rejected from the study. Before having a spirometry performed, subjects were given instructions about the procedures and side effects of the test. The subjects were recommended not to wear tight clothing that may interfere or make it difficult to take a deep breath. And they were also requested not to eat a large meal, drink alcohol, or do vigorous exercise for a few hours before the test.

The person being tested was asked to take in a full breath and then seal his lips around the mouthpiece of the spirometer. The person then had to blow out as hard and fast as possible for at least six seconds, which is the approximate time it takes for normal lungs to empty. A nose clip was applied to ensure no air escapes from the nose.This routine was repeated at least three times to ensure that the test was done correctly and to ensure accuracy of the results. Pulmonary function was assessed based on FEV, $\mathrm{FVC}$ and PEFR expressed as percent predicted for the age, sex, height, weight and race.

Spirometry was conducted in sitting position using MIR SPIROLAB II spirometer based on ATS recommendations. During the procedure the mean temperature and relative humidity in the city of Kathmandu was $22^{\circ} \mathrm{C}$ and $96 \%$ respectively. Body temperature and pressure saturation (BTPS) was autocorrected by the MIR SPIROLAB II spirometer. Statistical analysis: Non probability purposive judgment sampling method was used for this study. Analysis of variance (ANOVA) was used for inter-sport group's comparison. 


\section{Results:}

When comparing the mean values of FVC, $\mathrm{FEV}_{1}$ and PEFR among the different sport groups, as expected, athletes who have more strenuous respiratory muscles exercise had significantly superior pulmonary function parameters. Weight lifters, swimmers and marathoners had 111.84, 109.56 and 105.83 percentage of predicted values on FVC $(\mathrm{P}=0.008)$ respectively. Footballers and sprinters had 99.25 and 98.34 percentage of predicted values respectively. Weight lifters, swimmers and marathoners had 110.63, 110.15 and 110.28 percentages of predicted values on $\mathrm{FEV}_{1}(\mathrm{p}=0.090)$ respectively. Footballers had 102.52 and sprinters had 99.23. Swimmers and marathoners had highest recordings, 106.03 and 107.34 percentage of predicted values on PEFR $(p=0.027)$ respectively and footballers had 104.37, and weight lifters had 102.08 percentages of predicted values. But sprinters had 86.58, the lowest value recorded.

\section{Comparison of mean percentage predicted values on FVC, FEV 1 and PEFR}

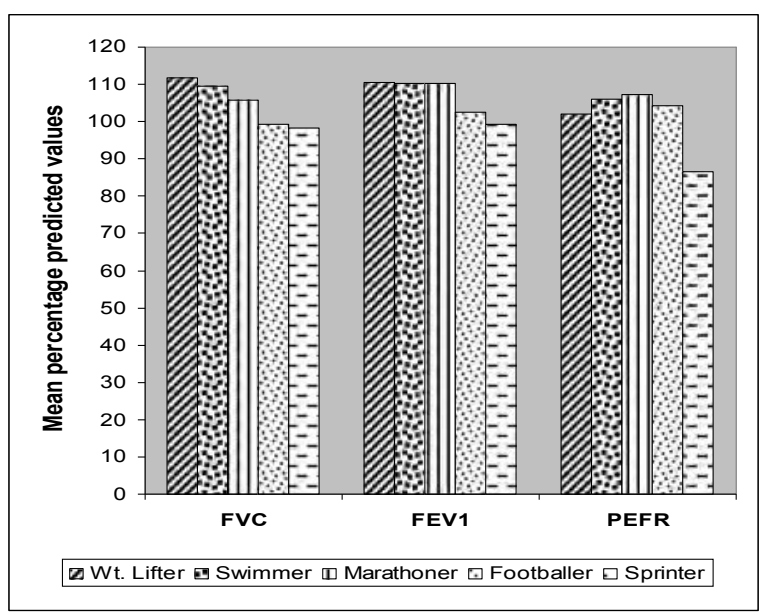

A statistically significant differences were found among the five different groups of athletes in FVC $\%$ of predicted, $F(4,79)=3.743, \mathrm{p}=0.008$, and in PEFR\% of predicted, $F(4,79)=2.895$, $\mathrm{p}=0.027$ but the difference was not significant in $\mathrm{FEV}_{1} \%$ predicted $\mathrm{F}(4,79)=2.087, \mathrm{p}=0.090$.
One way analysis of Variance summary tablecomparing different sport groups on FVC\% predicted, FEV\% predicted and PEFR\% predicted

\begin{tabular}{|c|c|c|c|c|c|c|}
\hline & & $\begin{array}{l}\text { Sum of } \\
\text { Squares }\end{array}$ & DF & $\begin{array}{l}\text { Mean } \\
\text { Square }\end{array}$ & $\mathbf{F}$ & Sig. \\
\hline \multirow{3}{*}{ FVC\% } & $\begin{array}{l}\text { Between } \\
\text { Groups }\end{array}$ & 2504.445 & 4 & 626.111 & 3.743 & .008 \\
\hline & $\begin{array}{l}\text { Within } \\
\text { Groups }\end{array}$ & 13214.774 & 79 & 167.276 & & \\
\hline & Total & 15719.219 & 83 & & & \\
\hline \multirow[t]{3}{*}{$\mathrm{FEV}_{1} \%$} & $\begin{array}{l}\text { Between } \\
\text { Groups }\end{array}$ & 1535.287 & 4 & 383.822 & 2.087 & .090 \\
\hline & $\begin{array}{l}\text { Within } \\
\text { Groups }\end{array}$ & 14526.770 & 79 & 183.883 & & \\
\hline & Total & 16062.057 & 83 & & & \\
\hline \multirow{3}{*}{ PEFR\% } & $\begin{array}{l}\text { Between } \\
\text { Groups }\end{array}$ & 2738.001 & 4 & 684.500 & 2.895 & .027 \\
\hline & $\begin{array}{l}\text { Within } \\
\text { Groups }\end{array}$ & 18677.958 & 79 & 236.430 & & \\
\hline & Total & 21415.959 & 83 & & & \\
\hline
\end{tabular}

\section{Discussion:}

Out of the five sport groups, weight lifters and swimmers had the highest initial lung parameters (FVC and $\mathrm{FEV}_{1}$ ). This is expected because in swimming, there is strenuous exercise of the respiratory muscles because the load of the water pressure against the chest wall and elevated airway resistance as the result of immersion could comprise a conditioning stimulus as well as the requirement that inspirations must occur rapidly from functional residual capacity during short intervals between strokes. Similarly, weight lifters have strong body muscles including the respiratory muscles 
resulting higher pulmonary functions. Sprinters had lower pulmonary parameters (FVC, FEV1, PEFR) compared to the athletes from other sports because short running practice does not improve respiratory muscles strength.

Doherty M, Dimitriou L in British journal of sports medicine 1997 state that running does not improve respiratory muscles strength but in this study pulmonary parameters (FVC, FEV1, and PEFR) have been recorded higher in marathon runners probably because of the cross sectional nature of the present study and the results cannot exclude some factors like training hours, genetic endowment, sample size etc. The result of this study concludes that the type of sports determines the pulmonary functions.

Athletes who have strenuous respiratory muscles exercise have better pulmonary function tests than those who have less strenuous muscle exercise. But other longitudinal studies are recommended to study about the changes in respiratory muscle strength in relation with time, training patterns (training duration, intensity) and contribution of genetic factor.

\section{References:}

1. Prakash S., Meshram S. and Ramtekkar U. Athletes, Yogis and Individuals with sedentary life styles; Do their lung functions differ? ; Indian Journal of Physiology and Pharmacology, 2007, 51 (1): 76-80.

2. Kippelen P, Caillaud C, Robert E, Connes $P$ et al. Effects of endurance training on lung function: a one year study; British Journal of Sports Medicine, 2005, 39: 617-621.
Effects of Sports on pulmonary functions

3. Doherty M, Dimitriou L. Comparison of Lung volume in Greek Swimmers, Land Based Athletes and sedentary controls using allometric scaling, British Journal of Sports Medicine, 1997, 31, 337341.

4. Lakhera SC ,Kain TC. Comparison of pulmonary function amongst Ladakhi Delhi, Vanvasi and Siddi boy athletes, Indian J Physiol. Pharmacol. 1995 Jul. 39 (3): 255-8.

5. Lakhera SC, Kain TC, Bandopadhyay P. Changes in lung function during adolescence in athletes and non athletes, J Sports Med Phys Fitness, 1994, Sep 34 (3): 258-262.

6. Lakhera SC, Mathew L, Rastogi SK, Sengupta J. Pulmonary function of Indian athletes and Sportsmen: comparison with American athletes. Indian J Physiol Pharmacol 1984 Jul- Sep 28(3): $187-94$.

7. Gupta N. The effects of different types of athletic training on pulmonary function in high school students; Chest, 2007; 6045.

8. Guyton CA, Hall JE. Text Book of Medical Physiology, $11^{\text {th }}$ ed. Philadelphia: Elsevier; 2006; 475-478.

9. Rundell KW, and Spiering BA. inspiratory stridor in elite athletes; Chest, 2003; 123, 468-474.

10. Chaudhuri, SK. Concise medical physiology. 2nd ed. Calcutta: new central book agency; 2006.

11. Saltin B. and Grimby G. Physioloical analysis of middle aged and old former athletes:

Comparison with still active athletes of the same ages. Circulation, 1968, 38, 1104-1115

Address of Correspondence: Dr Narayan Bahadur Mahotra, Department of Clinical Physiology, Maharajgunj Medicine Campus, Institute of Medicine, T. U. Maharajgunj, Kathmandu, Nepal. Tel: cell: 9841-574464 home: 01-4880019. Email: mahotranb@hotmail.com 